\title{
COVID-19: Complicando o rito da morte e o luto
}

\section{Márden Hott $^{1}$}

O Brasil e o mundo vivem uma verdadeira guerra biológica denominada Coronavirus disease, identificada no ano de 2019 (COVID-19) ou simplesmente "Novo Coronavírus". A patologia se instaurou em todos os continentes com potencialidade que fez o planeta parar e se absurdar. As ações visam o cuidar e focam, evidentemente, no problema global francamente incidente no processo saúde-doença. Este se desenha permeado por dilemas, opiniões divididas, intervenções insipientes e hipóteses (ainda) invalidadas, como em todo e qualquer novo cenário. Diante das incertezas se encontra a população (científica, médica, política, civil...) insegura e receosa.

As batalhas para prevenção e enfrentamento da enfermidade potencialmente fatal envolvem o desejo de "vitória" sobre a morte anunciada em larga escala. Porém, para que este objetivo seja alcançado é preciso envidar esforços nunca antes tão evidenciados nas áreas de pesquisa e inovação, associadas aos variados setores sociais. Por trás de todas as questões que envolvem o alto índice de contágio e o adoecer, se encontra o cume da afetação: o desfecho do fenecer e a luta incessante para que se consiga domá-lo controlando o agente causal.

Nem sempre a tentativa de evitabilidade do óbito prospera. Pessoas perdem a vida todos os dias e por causas diversas, sendo estas tanto quanto ou mais graves que o COVID-19, embora na maioria dos casos a progressão da letalidade em outras moléstias seja gradualmente diferenciada. Neste anômalo e invisível ambiente, surge o processo de morte e morrer de forma devastadora. O tema - interdito pela sociedade contemporânea brasileira - passou a ser a pauta diária, o que causa espanto no país em que a plenitude da felicidade é imposta, incluindo o evadir do sofrer [1].

Porém, antes ou durante a pandemia, os seres humanos cessaram e cessarão suas funções vitais em algum momento e, enquanto os entes queridos morrem, os enlutados nascem. Quando ocorre a morte, advém o luto e este, uma vez instaurado, se traduzi no temido padecer. O estado de enlutamento, por mais que seja um comportamento repreendido pela "humanidade" atual - avessa ao sofrimento (do outro) por não abrir espaço para a lamentação - é uma atribulação individual, porém influenciada (dentre outros) pela percepção de um auxílio que seja útil [2].

Caso o luto não seja bem elaborado, afetará não somente o portador, mas todo o seu contexto familiar e social, posto que esta aflição, ainda que agora pareça sensibilizar a coletividade, é sentida internamente, mas precisa do apoio externo para superação. Os humanos necessitam de uma fortalecida rede social de apoio, visto que as relações interpessoais fazem com que as pessoas moldem e sejam moldadas [3], para a vida e também para a morte. Indo além, o transtorno do luto está se desenhando como um problema de saúde pública em função da incidência de adoecidos pelo excesso de sofrimento, requerendo atenção e intervenção das áreas da psique [4].

\footnotetext{
${ }^{1}$ estagioeeff@yahoo.com.br
} 
O Manual Diagnóstico e Estatístico de Transtornos Mentais (DSM-5) no capítulo "Condições para estudos posteriores", aborda o Transtorno do Luto Complexo Persistente como um problema de saúde mesmo sem reconhecimento oficial, uma vez que postula mais estudos conclusivos; embora distinga luto "normal" de "complicado", utilizando o tempo de persistência e intensidade dos sintomas emocionais como marcador - doze meses para adultos e seis meses para crianças [5]. Reconhecer que o luto é um processo natural, mas que se não for bem concebido pode desencadear sérios problemas físicos e emocionais, já é um indicativo de que a temática não pode ser relegada.

Neste contexto, uma questão correlata - dentre tantas outras que não se pode negar - é a eficácia para a elaboração saudável do estado de enlutamento por meio da celebração fúnebre. Este é o ritual mais significativo para o ser humano que vivencia a perda parental: o respeito e a consagração do corpo desvitalizado. Independente da religiosidade ou espiritualidade aderida (ou não) todos querem velar e sepultar seus mortos. O velório (e sepultamento ou cremação) torna o espaço sagrado [6] e, para determinadas sociedades, somente através desses rituais a morte se legitima, pois o ser que não é inumado (recebendo o protocolo que se pretendia ilustrar a reverência), não está morto [7].

Contudo, esse epílogo que detém simbolismo de extrema relevância, confronta com uma pandemia sem precedentes nesse limiar e que alterou o como, o quando e o onde se despedir. Os ritos ganharam nova dinâmica, perdendo o esboço do que era prosaico, ferindo a cultura do culto por transgredir o imprescindível para cada ser "remanescente" que se sente afetado. No Brasil, as simbologias da morte, como as cerimônias que incluem o velar e o sepultar, são significativas para mobilização das pessoas em momento de crise suprema [8]. É fato que as medidas de vigilância sanitária imperam para o bem-estar da coletividade e se tornou difícil compreender que os cemitérios cau uma vez que a matéria orgânica enterrada é composta por várias espécies de bactérias e vírus, possivelmente causadores do óbito [9]

Entretanto, a necessidade de lidar com o isolamento social e todas as suas consequências é algo que, apesar de real, consta como circunstância sobre-humana. Assim, o falecimento de um ente querido por si só é suficiente para desencadear transtornos psíquicos de alta complexidade e ao associá-lo às variáveis que o coronavírus obrigatoriamente institui, alarga as possibilidades. $\mathrm{O}$ afastar do doente durante o tratamento, o aguardar por notícias que demoram a ser proferidas, a espera pelo providenciar burocrático de corpos preservados em câmaras frias ou se decompondo a esmo, a identificação incorreta do falecido (ou a falta desta), a ausencia da presença daqueles que seriam indispenśa is no instante do ve daqueles que tambor se fazeis no instante do velorio (instante também por se fazerem com rapidez sem precedente de outorga ou inexistirem), o sepultar em urnas lacradas e por vezes em túmulos coletivos, são fatos que, acumulados ou não, provavelmente contribuirão de forma negativa para o triunfo sobre o luto.

O enlutado, especialmente o complicado, requer a manutenção da memória do ente querido falecido com alteridade e esta ação angustiante da suspensão do viver (do outro, mas que também pode desencadear em si) abre uma aporia fundamental para delinear as transformações do porvir, tornando cara a desconstrução [10], especialmente de tudo o que espelha sofrimento e solidão. Não era rara a complexidade da reestruturação de signos e significados da morte no transtorno do luto em casos preg distúrbios emocionis podem ser catastróficos, visto que as estratégias de enfrentamento sucumbem [11]

Ainda não se encontrou uma maneira de reformular a questão referente às celebraçōes mortuárias que precisam, por inquestionável questão profilática, ter o cerceamento parcial ou total das práxis triviais Não obstante, 0 pandemia - st a ser pensado. Enquara o mundo visumbra o cenario após O COVD-19, Tanto o mundo vislumbra o cenário apos o covD-19, tambem é preciso entrever dentro desta perspectiva, como ficarăo os sobreviventes, não somente aqueles que foram contagiados e venceram a doença, ou os que de alguma forma se afetaram pela mesma, mas também aqueles que vivenciaram seus entes sucumbirem a ela (e a outras), e não puderam se despedir através dos ritos como endências e essências existenciais fundamentais para impulsionar o pretencioso "seguir em frente".

\section{REFERÊNCIAS}

1. Bezerra B. A psiquiatria e a gestão tecnológica do bemestar. In: FILHO, J. F. (Org.). Ser feliz hoje. Reflexões sobre o mperativo da felicidade 1. ed. Rio de Janeiro: FGV Editora, 2010. p. 213-226
2. Franqueira AMR, Magalhães AS. Compartilhando a dor: O papel das redes sociais no luto parental. Revista Pesquisa Qualitativa. São Paulo (SP). 2018. 6(11):373-389. DOl: http:/ dx.doi.org/10.33361/RPQ.v.6.n.11

3. Hoffmann FS, Müller MC, Rubin R. A mulher com câncer de mama: apoio social e espiritualidade. Mudanças Psicologia da Saúde. 2006;14(2):143-150. DOl: http://dx.doi. org/10.15603/2176-1019/mud.v14n2p143-150

4. Kovács MJ. Educação para a morte. Psicologia: ciência profissão. 2005; 25 (3):484-497. https:///doi.org/10.1590/ S1414-98932005000300012

5. American Psychiatric Association. Manual diagnóstico e estatístico de transtornos mentais: DSM-5 (5a ed.). Porto Alegre, RS: Artmed; 2014

6. Balandier G. A desordem. Elogio do movimento. Rio de Janeiro: Bertrand Brasil; 1997.

7. Eliade M. O sagrado e o profano: a essência das religiões. São Paulo: Martins Fontes; 1996.

8. Malinowski B. Magia, ciência e religião. Lisboa: Edições 70; 1984

9. Xavier CC, Amorim MR, Valentini CMA, Faria RAPG Diagnóstico da situação atual dos cemitérios em Cuiabá-MT sob a ótica da gestão ambiental: Estudo de caso Parque Bom Jesus de Cuiabá e Cemitério São Gonçalo. Revista Eletrônica Jesus de Cuiabá e Cemitério São Gonçalo. Revista Eletrônica em Gestão, Educação e Tecnologia Ambiental. Santa Ma
2015;19 (3):450-461. DOI: 105902/2236117016964.

10. Pereira BVC. Derrida e a tragédia: o quase-conceito de luto em Antígona. Analógos, Rio de Janeiro. 2016;1:22-32. DOI: 10.17771/PUCRio.ANA.28124.

11. Parkes CM. Amor e Perda - As raízes do luto e suas complicações. São Paulo: Summus, 2009. 